\title{
Optical properties and aging of light-absorbing secondary organic aerosol
}

\author{
Jiumeng Liu ${ }^{1}$, Peng Lin ${ }^{2}$, Alexander Laskin ${ }^{2}$, Julia Laskin $^{3}$, Shawn M. Kathmann ${ }^{3}$, Matthew Wise ${ }^{4}$, Ryan Caylor ${ }^{4}$, \\ Felisha Imholt ${ }^{4}$, Vanessa Selimovic ${ }^{4, a}$, and John E. Shilling ${ }^{1}$ \\ ${ }^{1}$ Atmospheric Sciences and Global Change Division, Pacific Northwest National Laboratory, Richland, WA, USA \\ ${ }^{2}$ Environmental Molecular Sciences Laboratory, Pacific Northwest National Laboratory, Richland, WA, USA \\ ${ }^{3}$ Physical Sciences Division, Pacific Northwest National Laboratory, Richland, WA, USA \\ ${ }^{4}$ Math and Science Department, Concordia University, Portland, OR, USA \\ anow at: Department of Chemistry, University of Montana, Missoula, MT 59812, USA \\ Correspondence to: John E. Shilling (john.shilling@pnnl.gov)
}

Received: 8 June 2016 - Published in Atmos. Chem. Phys. Discuss.: 13 June 2016

Revised: 18 September 2016 - Accepted: 19 September 2016 - Published: 14 October 2016

\begin{abstract}
The light-absorbing organic aerosol (OA) commonly referred to as "brown carbon" $(\mathrm{BrC})$ has attracted considerable attention in recent years because of its potential to affect atmospheric radiation balance, especially in the ultraviolet region and thus impact photochemical processes. A growing amount of data has indicated that $\mathrm{BrC}$ is prevalent in the atmosphere, which has motivated numerous laboratory and field studies; however, our understanding of the relationship between the chemical composition and optical properties of $\mathrm{BrC}$ remains limited. We conducted chamber experiments to investigate the effect of various volatile organic carbon (VOC) precursors, $\mathrm{NO}_{x}$ concentrations, photolysis time, and relative humidity $(\mathrm{RH})$ on the light absorption of selected secondary organic aerosols (SOA). Light absorption of chamber-generated SOA samples, especially aromatic SOA, was found to increase with $\mathrm{NO}_{x}$ concentration, at moderate $\mathrm{RH}$, and for the shortest photolysis aging times. The highest mass absorption coefficient (MAC) value is observed from toluene SOA products formed under high- $\mathrm{NO}_{x}$ conditions at moderate $\mathrm{RH}$, in which nitro-aromatics were previously identified as the major light-absorbing compounds. BrC light absorption is observed to decrease with photolysis time, correlated with a decline of the organic nitrate fraction of SOA. SOA formed from mixtures of aromatics and isoprene absorb less visible (Vis) and ultraviolet (UV) light than SOA formed from aromatic precursors alone on a mass basis. However, the mixed SOA absorption was underestimated when optical properties were predicted using a two-product SOA forma-
\end{abstract}

tion model, as done in many current climate models. Further investigation, including analysis on detailed mechanisms, are required to explain the discrepancy.

\section{Introduction}

Climate forcing by various atmospheric components has been intensely investigated over the last few decades but significant uncertainties still exist (IPCC, 2013). One of the largest uncertainties comes from the role of carbonaceous aerosols, including black carbon (BC) and organic carbon (OC). Black carbon is formally defined as an ideally light-absorbing substance composed of carbon (Petzold et al., 2013) with strong absorption across a wide spectrum of visible wavelengths, which is caused by a significant, wavelength-independent imaginary part $k$ (i.e., $\sim 0.79$; Bond et al., 2013) of the refractive index. BC has long been known as the strongest light-absorbing aerosol in the visible wavelengths (e.g., Bond et al., 2013). On the other hand, OC has been treated as a scattering species, and only a few recent global modeling studies have focused on the radiative forcing by absorbing OC (G. Lin et al., 2014; Feng et al., 2013; Chung et al., 2012). Light-absorbing organic aerosol (OA) are collectively called brown carbon (BrC) (Laskin et al., 2015; Moise et al., 2015; Andreae and Gelencsér, 2006). In contrast to $\mathrm{BC}$, the imaginary refractive index of $\mathrm{BrC}$ has stronger wavelength dependence $\left(\lambda^{-2}-\lambda^{-6}\right)$ that in- 
creases towards shorter visible and ultraviolet (UV) wavelengths. This broad absorption band in the blue/violet region of the spectrum gives $\mathrm{BrC}$ its eponymous yellow or brown color (Alexander et al., 2008; Andreae and Gelencsér, 2006; Lukács et al., 2007). BrC has been widely observed in many environments, including urban environments largely impacted by anthropogenic emissions (Zhang et al., 2013; Du et al., 2014), biomass burning plumes (Lack et al., 2012, 2013; Forrister et al., 2015), over the ocean (Bikkina and Sarin, 2013), rainwater (Kieber et al., 2006), and in the troposphere (Liu et al., 2014; Alexander et al., 2008).

A variety of studies have investigated sources of $\mathrm{BrC}$ in both the laboratory and in the field. Incomplete and smoldering combustion of hydrocarbons, especially those associated with biomass burning, is known to directly produce particulate $\mathrm{BrC}$ (Hoffer et al., 2006; Hecobian et al., 2010; Lack et al., 2013; Desyaterik et al., 2013; Chakrabarty et al., 2010; Kirchstetter and Thatcher, 2012; Mohr et al., 2013). There is also evidence based on ambient studies of a secondary $\mathrm{BrC}$ source (Duarte et al., 2005) and laboratory studies show formation of chromophores (components of molecules that absorb light) through a variety of mechanisms, including photooxidation of aromatics (Lambe et al., 2013; P. F. Liu et al., 2015), ozonolysis of terpenes subsequently aged in the presence of ammonium ions and humidity (Bones et al., 2010; Nguyen et al., 2013; Laskin et al., 2014; Updyke et al., 2012), and a variety of additional aqueous phase reactions, such as lignin (Hoffer et al., 2006) and isoprene oxidation (Limbeck et al., 2003), reactions of carbonyls (e.g., glyoxal, methyglyoxal) in acidic solutions (Sareen et al., 2010), with amino acids (De Haan et al., 2009), amines (De Haan et al., 2009; Powelson et al., 2014; Zarzana et al., 2012), or ammonium salts (Sareen et al., 2010; Lin et al., 2015a; Galloway et al., 2009; Kampf et al., 2012; Shapiro et al., 2009). Among those studies, it is suggested that the chemical and optical properties of laboratory-generated secondary organic aerosols (SOA) might be influenced by a variety of factors, including the composition of the volatile organic carbon (VOC) precursor, oxidation chemistry, relative humidity (RH), and potentially "aging" at longer timescales (i.e., in-particle reactions and photobleaching). Particularly, SOA aged in the presence of dissolved ammonium has been shown to produce $\mathrm{BrC}$ efficiently, which may contribute to aerosol optical density in regions with elevated concentrations of ammonium salts (i.e., Updyke et al., 2012).

This study focuses on measuring light absorption by laboratory-generated SOA that simulate both urban and remote environments. Four VOCs representative of biogenic and anthropogenic emission are chosen as SOA precursors in this study. Biogenic VOCs selected include isoprene and $\alpha$-pinene, of which isoprene is the most abundant biogenic non-methane hydrocarbon emitted into the atmosphere (Guenther et al., 2006), while $\alpha$-pinene accounts for approximately $40 \%$ of global monoterpene $\left(\mathrm{C}_{10} \mathrm{H}_{16}\right)$ emissions (Guenther et al., 2012). For anthropogenic VOCs, we se- lected trimethylbenzene (TMB) and toluene, the photooxidation of which in the presence of $\mathrm{NO}_{x}$ is a major source of anthropogenic SOA (Ng et al., 2007; Kleindienst et al., 2004; Henze et al., 2008). Four different types of experiments were conducted to investigate the effects of (1) $\mathrm{NO}_{x}$ levels, (2) VOC precursors, (3) photolysis time, and (4) RH on SOA light absorption. We compare the UV-Vis absorption light absorption of these SOA samples extracted in both water and methanol.

\section{Experimental methods}

Experiments were performed in the indoor $10.6 \mathrm{~m}^{3}$ Teflon chamber at the Pacific Northwest National Laboratory (PNNL) operating in batch mode where a discrete quantity of a VOC is introduced into the chamber and allowed to react with the gas-phase oxidants (Liu et al., 2012). The Teflon chamber was flushed continuously with dry purified air until particle concentrations were less than $5 \mathrm{~cm}^{-3}$ prior to all experiments. For each experiment, a measured amount of VOC was injected into a glass bulb with a syringe, evaporated with gentle heating, and transferred to the chamber in a flow of purified air. After the VOC injection, $0.5 \mathrm{~mL}$ of $\mathrm{H}_{2} \mathrm{O}_{2}$ solution (Sigma-Aldrich, $50 \mathrm{wt} \%$ in $\mathrm{H}_{2} \mathrm{O}$ ) was injected into the chamber in the same manner. Humidity was controlled by passing pure air at a variable flow rate through pure water $(18.2 \mathrm{M} \Omega \mathrm{cm},<5 \mathrm{ppbv}$ TOC) with a HEPA filter downstream of the bubbler to remove any contaminant particles. In experiments in which $\mathrm{NO}_{x}$ were present, $\mathrm{NO}$ was injected from a gas cylinder containing a known NO concentration $\left(500 \mathrm{ppm}\right.$, Matheson Tri-Gas $\left.{ }^{\circledR}\right)$ with flows regulated by mass flow controllers. After all components were injected and well mixed in the chamber, UV lights were turned on to initiate photooxidation. The UV flux in the chamber, averaged $J_{\mathrm{NO}_{2}}=0.16 \mathrm{~min}^{-1}$, was measured continuously by a radiometer that is calibrated to an equivalent photolysis rate of $\mathrm{NO}_{2}$ and suspended in the center of the chamber. Measurements of $J_{\mathrm{NO}_{2}}$ using the photostationary state method were in agreement with the radiometer measurements (Leighton, 1961).

During the experiments, a suite of online instruments were used to characterize the gas- and particle-phase composition. The mixing ratios of the hydrocarbons were continuously monitored with an Ionicon proton-transfer-reaction mass spectrometry (PTR-MS). The mass loading of the aerosol particles was measured using an Aerodyne highresolution time-of-flight mass spectrometer (HR-ToF-AMS) (DeCarlo et al., 2006), while the number and volume concentrations were measured with a TSI scanning mobility particle sizer (SMPS). An NO/NO $/ \mathrm{NO}_{x}$ analyzer (Thermo Environmental Instruments model $42 \mathrm{c}$ ) was used to measure the concentration of $\mathrm{NO}$ and $\mathrm{NO}_{x}$. A UV absorption $\mathrm{O}_{3}$ analyzer (Thermo Environmental Instruments model 49C) allowed for the measurement of $\mathrm{O}_{3}$ concentration. 
SOA samples were collected on filters to measure their light absorption. Photooxidation products were collected onto polytetrafluoroethylene (PTFE) filters (Pall Life Sciences, $47 \mathrm{~mm}, 1 \mu \mathrm{m}$ pore size) at a flow rate of $9 \mathrm{~L} \mathrm{~min}-1$ for a collection period of $60-120 \mathrm{~min}$. Typically at least $20 \mu \mathrm{g}$ of organic mass is required for accurate measurement of light absorption. As described in previous studies (Hecobian et al., 2010; Zhang et al., 2011), filters were extracted in high purity water $(>18.2 \mathrm{M} \Omega \mathrm{cm})$, filtered through a $25 \mathrm{~mm}$ diameter $0.45 \mu \mathrm{m}$ pore syringe filter (Fisher Scientific, Fisherbrand ${ }^{\mathrm{TM}}$ Syringe Filters) and transferred into a long-path (100 cm pathlength) UV-Visible spectrometer (Ocean Optics) to determine the light-absorption spectra. After water extraction, filters were also sonicated in methanol (VWR International, A.C.S. Grade) to extract non-water soluble mass (Liu et al., 2013; J. Liu et al., 2015). Total absorption due to $\operatorname{BrC}(\operatorname{Abs}(\lambda))$ is determined as the sum of watersoluble and methanol-extracted absorption from the sequential extraction processes. An extraction efficiency test was performed with six filters, in which filters were cut in halves, one-half extracted with methanol only and the other half processed with the sequential extraction. Results show that the sum of light absorption from the sequential extraction is comparable to methanol extraction alone, with a slope within $8 \%$ of 1 (Fig. S1 in the Supplement). Studies have shown that the extraction efficiency of organic mass is $>90 \%$ using methanol as the solvent (Chen and Bond, 2010; Updyke et al., 2012). Thus, it is reasonable to assume that total light absorption determined from the sequential extraction procedure closely approximates the "true" optical properties of the SOA samples. The limit of detection (LOD) was $0.081 \mathrm{Mm}^{-1}$ in the $300-700 \mathrm{~nm}$ wavelength range with an estimated uncertainty of $21 \%$. The mass absorption coefficient (MAC) was then estimated using Eq. (1):

$\operatorname{MAC}(\lambda)=\frac{\operatorname{Abs}(\lambda)}{\mathrm{OM}}$

in which $\operatorname{Abs}(\lambda)$ is the light absorption from filter-collected aerosol samples at a wavelength $\lambda$, and OM (organic materials) is the SOA mass concentrations on the filter estimated from AMS measurements and the sampled air volume. Wall-loss corrections were not applied to either measured SOA mass concentrations or light absorption determined from filter-collected aerosol samples for consistency. Based on lowest SOA mass concentrations during all experiments, the LOD of the MAC is estimated as $0.004 \mathrm{~m}^{2} \mathrm{~g}^{-1}$.

\section{Description of the SOA two-product model}

Ambient studies have shown that SOA produced from urban emissions in isoprene-rich environments tend to have much lower $\mathrm{BrC}$ absorption compared to that in anthropogenic emission-dominant environments (Zhang et al., 2011). In our study, two mixed-precursor experiments were conducted to investigate the changes in aromatic $\mathrm{BrC}$ due to the addi- tion of isoprene reaction products. We employ a two-product model to describe the partitioning of organic mass between aromatic- and isoprene-derived SOA (Pankow, 1994; Odum et al., 1996). SOA yield parameters for pure compounds are determined by fitting real-time batch-mode data as described in the literature (Presto and Donahue, 2006). In the mixedprecursor experiments, the PTR-MS data are used to determine the amount each precursor reacted during the filter collection periods. Then, the pure compound yield parameterizations are used to calculate the relative fractions of the isoprene- and aromatic-derived SOA collected on the filter. The calculation assumes that all SOA components are mutually miscible and reproduced the measured SOA mass with a difference of less than $10 \%$ (Table S2). These fractions are then used along with the optical properties of the singleprecursor SOA to predict the optical properties of the mixed aerosol.

\section{Results and discussion}

\subsection{Effects of VOC types and $\mathrm{NO}_{x}$ levels}

The wavelength-dependent MAC values for SOA derived from four selected precursor VOCs are plotted in Fig. 1. In general, the shapes of the spectra are characteristic of typical atmospheric $\mathrm{BrC}$ materials, with relatively higher absorption in the UV range (i.e., Hecobian et al., 2010; Chen and Bond, 2010). Figure 2 shows a comparison of the MAC at $365 \mathrm{~nm}$ among four different SOA samples (isoprene, $\alpha$ pinene, TMB and toluene) produced under $\mathrm{NO}_{x}$-free and high- $\mathrm{NO}_{x}$ conditions.

The MAC values of isoprene SOA are close to the LOD in the $300-700 \mathrm{~nm}$ wavelength range and there is no significant difference in the UV-Vis spectra of isoprene SOA formed under $\mathrm{NO}_{x}$-free and high- $\mathrm{NO}_{x}$ conditions. Quantum mechanical calculations suggest that electrons must be delocalized over the equivalent of 7-8 bond lengths before an absorption will occur at $360 \mathrm{~nm}$ (Kuhn, 1949). Therefore, our results suggest SOA produced from isoprene photochemical oxidation does not contain products that have extended carbon conjugated chains, consistent with current understanding that isoprene photochemical oxidation products consist of carbonyls, hydroxycarbonyls, diols, and organic peroxides (e.g., Nguyen et al., 2011). On the other hand, Y.-H. Lin et al. (2014) has suggested that acidic seeds may promote formation of oligomers through reactive uptake of IEPOX and produced light-absorbing OA under certain conditions. In our experiments, neither acidic seeds nor excess ammonia are present, which could explain the difference between our observations and those of Y.-H. Lin et al. (2014).

Compared to isoprene SOA, SOA formed from photochemical oxidation of $\alpha$-pinene showed slightly higher absorption in the $300-350 \mathrm{~nm}$ wavelength range, though the absolute MAC values are still small. We observe a slight in- 

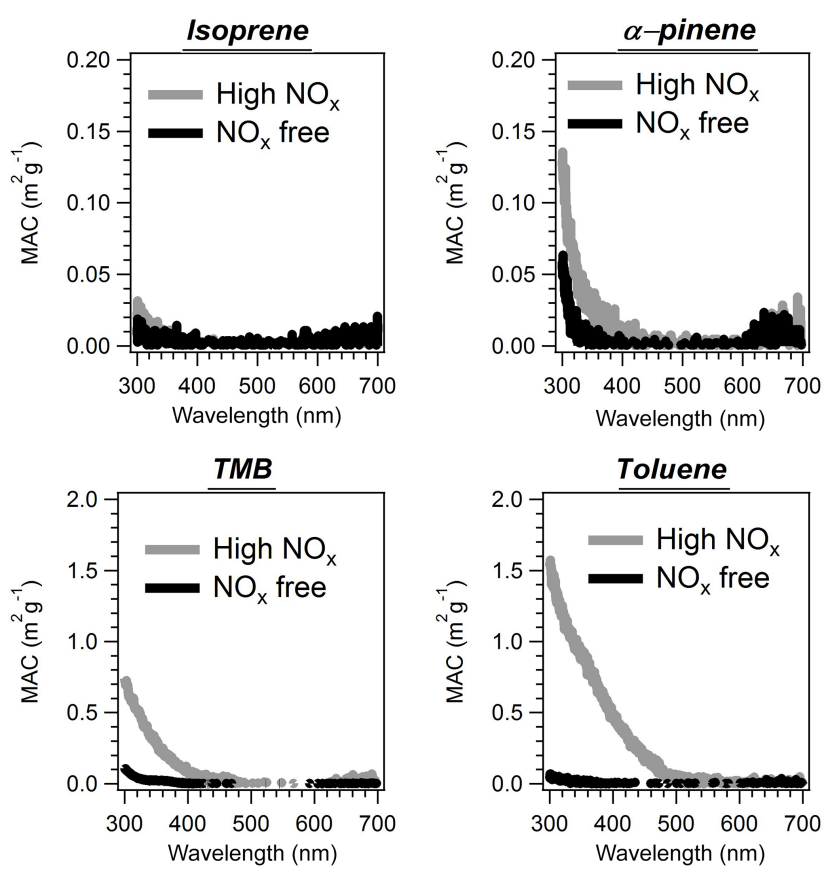

Figure 1. MAC values for SOA formed under $\mathrm{NO}_{x}$-free and high$\mathrm{NO}_{x}$ conditions, from isoprene, $\alpha$-pinene, TMB, and toluene. Note the $10 \times$ difference in scale between the terpene and aromatic precursors. The MAC values shown in this figure are tabulated in the Supplement (Table S1).

crease in the MAC values at wavelengths below $450 \mathrm{~nm}$ for the $\alpha$-pinene SOA formed under high- $\mathrm{NO}_{x}$ conditions relative to that formed in the absence of $\mathrm{NO}_{x}$. These observations are consistent with other studies that have found minimal light absorption for $\alpha$-pinene SOA, again indicating that the compounds partitioning to the condensed phase do not have extended conjugation (Henry and Donahue, 2012; Nakayama et al., 2010; Laskin et al., 2014).

In contrast to the SOA produced from the terpene precursors, aromatic precursors representative of anthropogenic VOCs produce SOA that significantly absorbs light, particularly in the UV wavelength range. Overall, the MAC values of the SOA produced from both TMB and toluene are much higher than biogenic SOA, for both $\mathrm{NO}_{x}$-free and high- $\mathrm{NO}_{x}$ conditions (Fig. 2). Lambe et al. (2013) suggested that the conjugated double bonds retained in oxidation products of aromatic precursors are likely to contribute to absorption in the ultraviolet to near-visible range. SOA formed from nonaromatic precursors, on the other hand, did not show strong light absorption in the ultraviolet-visible range due to lack of extended conjugated double bond networks.

For both toluene and TMB SOA, high- $\mathrm{NO}_{x}$ products show substantially higher light absorption than low $\mathrm{NO}_{x}$. Shown in Figs. 1 and 2, aromatic SOA formed under high- $\mathrm{NO}_{x}$ conditions have much higher MAC values, both in the UV and in the visible. Several studies, based upon both chamber and

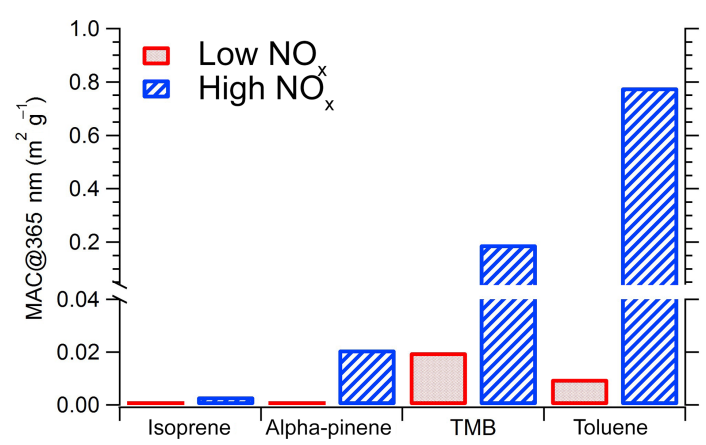

Figure 2. Comparison of MAC from various types of SOA, at a wavelength of $365 \mathrm{~nm}$.

field observations, have suggested that nitrogen-containing molecules are strong light absorbers (i.e., Nakayama et al., 2013; P. F. Liu et al., 2015; Zhang et al., 2011; Lin et al., 2015b). In a companion study, we reported detailed characterization of the most prominent $\mathrm{BrC}$ chromophores in toluene SOA formed under both $\mathrm{NO}_{x}$-free and high- $\mathrm{NO}_{x}$ conditions by deploying liquid chromatography combined with a UV-Vis detector and high-resolution mass spectrometry (LC-UV/Vis-ESI/HRMS) (Lin et al., 2015b). Samples of toluene SOA produced under high- $\mathrm{NO}_{x}$ and $\mathrm{NO}_{x}$-free conditions have substantially different chemical compositions. In high- $\mathrm{NO}_{x} \mathrm{SOA}$, we identified 15 nitro-aromatic compounds, including nitrocatechol, dinitrocatechol, and nitrophenol, the total absorbance of which accounts for 60 and $41 \%$ of the overall absorbance in the wavelength ranges of 300-400 and 400-500 nm, respectively (Lin et al., 2015b). In contrast, photooxidation products observed in $\mathrm{NO}_{x}$-free SOA are dominated by non-aromatic compounds with a high degree of saturation, which did not show substantial light absorption in the UV-Vis range. Similar to toluene SOA, TMB SOA produced under high- $\mathrm{NO}_{x}$ conditions contains nitrogen-containing compounds in contrast to $\mathrm{NO}_{x}$-free SOA, which explains the difference in light-absorbing properties (Liu et al., 2012).

For similar reaction conditions, the TMB-derived SOA samples are less absorptive than the toluene SOA. The difference in the light absorption properties between toluene SOA and TMB SOA may be explained by the difference in the production of nitrophenols. Sato et al. (2012) showed that nitrophenols were not detected in the TMB SOA, possibly due to the fact that $\mathrm{NO}_{2}$ addition to the phenoxy radical formed in reaction of TMB with $\mathrm{OH}$ is inhibited. Our measurement is consistent with this hypothesis and infers that nitro-aromatics such as nitrophenols are the main sources of light absorption for the aromatic SOA.

The MAC values of SOA produced from aromatic VOCs are comparable to those of other light-absorbing material relevant to atmospheric aerosol particles, such as fulvic acid. Shown in Fig. 3a, the blue shaded area represents the measured MAC range of SOA produced in the toluene $+\mathrm{NO}_{x}$ ex- 

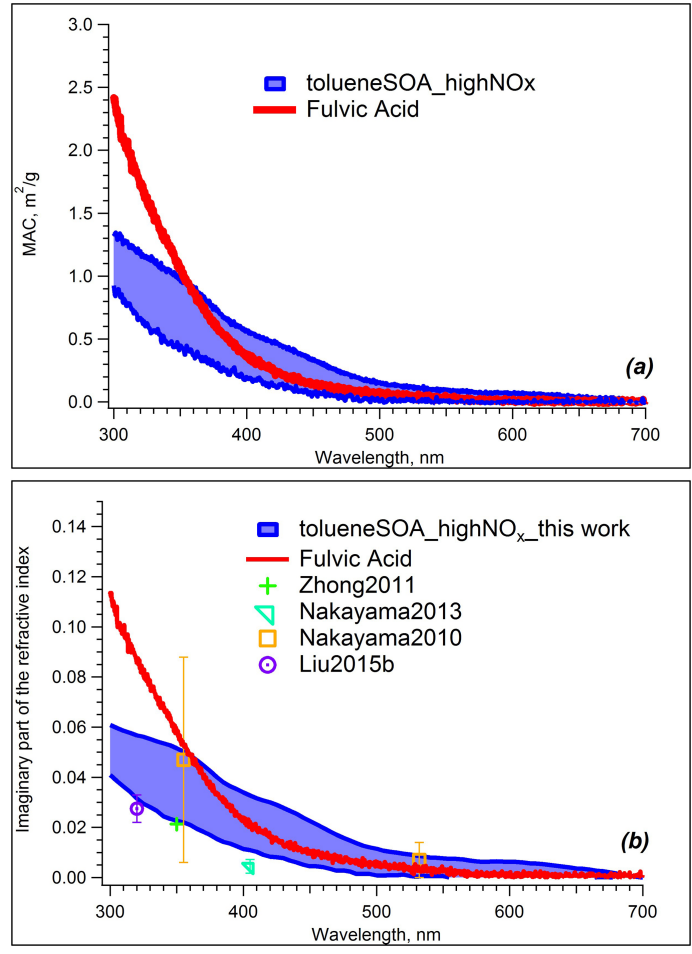

Figure 3. (a) MAC values of Suwanee River fulvic acid (SRFA), and toluene SOA formed at different high-NO $\mathrm{N}_{x}$ conditions. (b) Imaginary part of the refractive index, $k$, derived from toluene high- $\mathrm{NO}_{x}$ SOA measurements through the 300-700 nm range, with SRFA and literature data as references (Nakayama et al., 2010, 2013; Liu et al., 2015b; Zhong and Jang, 2011). SRFA $k$ values were estimated assuming a density of $1.47 \mathrm{~g} \mathrm{~cm}^{-3}$ (Dinar et al., 2006).

periments, with the MAC of Suwannee River fulvic acid as a reference. Over the wavelength range $380-480 \mathrm{~nm}$, toluene SOA has higher MAC values than fulvic acid. Since fulvic acid is often cited as a surrogate of strong light-absorbing atmospheric $\mathrm{BrC}$ associated with biomass burning, this comparison shows that light absorption by $\mathrm{BrC}$ produced from anthropogenic VOCs can be significant under certain photochemical condition, consistent with high MAC values measured previously in urban environments when biomass burning impacts were low (e.g., Zhang et al., 2011, 2013; Liu et al., 2013).

\subsection{Mixed-precursor experiments}

Results from laboratory studies have shown that the addition of isoprene reduced the $\mathrm{BrC}$ absorption of aerosols formed from toluene $+\alpha$-pinene mixtures (Jaoui et al., 2008). The lower absorption was attributed to decreased organic aerosol yields (e.g., lower amounts of light-absorbing SOA were formed) (Jaoui et al., 2008). From ambient observations, Zhang et al. (2011) reported contrasting light absorption properties in two urban environments. Fresh SOA in Los Angeles displayed much higher light-absorption presumably be-
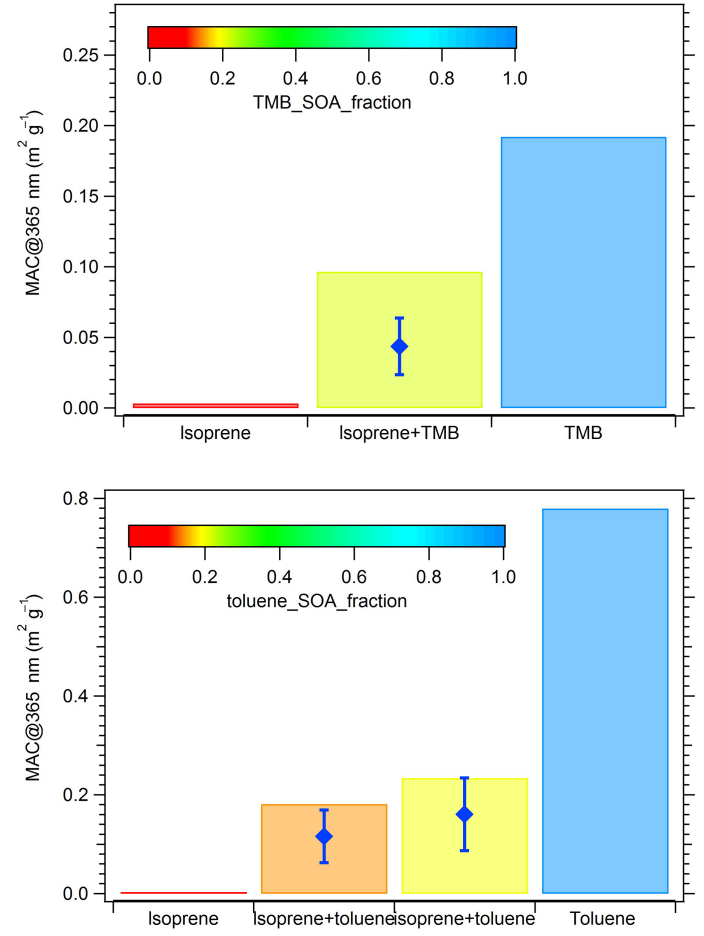

Figure 4. Comparison of MAC values from single-precursor and mixed-precursor experiments. Bars represent the MAC values at $365 \mathrm{~nm}$ from measurements, and are color-coded by the mass fraction of aromatic SOA. The blue diamonds represent the predicted MAC values based on the modeled fraction of isoprene SOA and aromatic SOA, with error bars indicating the uncertainty.

cause of the anthropogenic-dominated environment, whereas Atlanta aerosols formed from a mix of anthropogenic and biogenic (isoprene) VOC precursors had a 4-6 times lower MAC value. Hecobian et al. (2010) measured the light absorption of water-soluble organic carbon (WSOC) in Atlanta in different seasons and found that the winter WSOC has a $\sim 3$ times higher MAC than summer, due to a higher fraction of organic aerosols formed from biogenic VOCs in summer. Using summertime samples collected in Atlanta, Liu et al. (2013) reported a significantly higher BrC MAC value that was associated with primary anthropogenic emissions, compared to the lower MAC value observed at sites with local anthropogenic emissions on top of regional biogenic-dominant emissions. To investigate whether isoprene photooxidation products enhance or inhibit absorption of aromatic SOA, we conducted two mixed-precursor experiments. Figure 4 shows the comparison of MAC values at $365 \mathrm{~nm}$ of SOA formed from single precursor and from mixed isoprene and aromatic VOCs, under high- $\mathrm{NO}_{x}$ conditions. In both isoprene/toluene and isoprene/TMB experiments, the SOA formed has lower MAC values than those formed from the pure aromatics alone. Qualitatively, this is the behavior that one would expect, since non-absorbing isoprene SOA will "dilute" the chromophores from the aromatic-derived SOA. To determine 
whether the total aerosol absorption can be described quantitatively, we first estimate the mass of aromatic- and isoprenederived SOA (Table S2) using a partitioning model described in the "Description of the SOA two-product model" section. We then calculate predicted aerosol MAC values as the mass-weighted average of the MAC values measured for the pure isoprene- and aromatic-derived SOA species. Figure 4 shows a comparison of the measured and predicted mixedprecursor SOA optical properties. The predicted MAC values are 31-55\% lower than the measurements, a difference that is likely outside of the measurement uncertainty. There are several potential explanations for the difference between the predicted and observed MAC values. First, it is possible that SOA formation is not well-described by partitioning theory. One potential source of error in our calculation is that we assume isoprene and aromatic SOA are fully miscible in one another; however, we note that the total predicted SOA mass is within $10 \%$ of the observed SOA mass and hence the underprediction of the MAC values cannot be explained by this error. A second possibility is that the partitioning model underestimates the mass of aromatic SOA that has condensed into the mixed-phase particles. Studies have shown that gas-phase wall loss of toluene reaction products can be significant under certain conditions in batch-mode experiments (Zhang et al., 2014). The SOA yield parameterizations are based on data collected in the absence of seed particles, in which case gas-phase wall loss could be significant. However, isoprene reacts much more quickly than toluene (Fig. S2); therefore, isoprene SOA should form first and provide surface area which should mitigate the gas-phase wall loss of the toluene reaction products. Because no seed particles were present in the pure toluene experiments, we would expect those yield values to be biased low relative to the toluene yield in the mixed-precursor experiments, thus potentially explaining the underprediction of MAC values. A third possibility is that organic peroxides and alcohols, which were shown to be the dominant component of isoprene SOA (Krechmer et al., 2015), may react with toluene SOA components to produce oligomers capable of absorbing in the UVVIS that are not present in the single-precursor SOA particles. Examination of the AMS spectra in the mixed experiments and comparison to the spectra of the pure aromaticand isoprene-SOA were inconclusive in providing evidence of this hypothesis. Samples were not collected for detailed analysis by LC-UV/Vis-ESI/HRMS. Therefore, at this time we cannot conclusively explain the apparent absorption enhancements we observe.

\subsection{Effect of relative humidity on light absorption by aromatic SOA}

In order to investigate the effect of RH on SOA light absorption, both toluene and TMB photo-oxidation experiments were conducted at fixed VOC and $\mathrm{NO}_{x}$ values but variable RH levels (Table 1). Figure 5 illustrates the light absorption
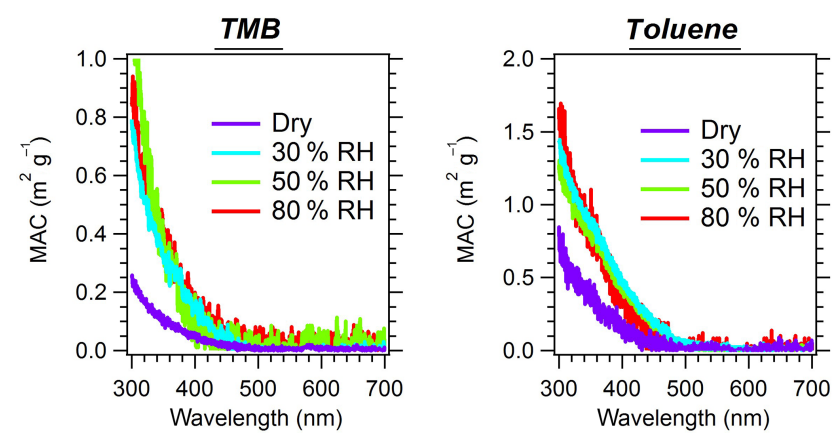

Figure 5. MAC spectra of TMB and toluene SOA formed at $<5$, 30,50 , and $80 \% \mathrm{RH}$.

spectra of toluene- and TMB-derived SOA as a function of experimental RH. The data shown here were from samples collected at a photolysis time of $200 \mathrm{~min}$, which corresponds to the time when light absorption reached its highest value. In both TMB and toluene experiments, SOA generated under dry conditions $(\mathrm{RH}<5 \%)$ displayed significantly lower MACs than SOA formed at RH $>30 \%$. SOA formed at 30 , 50 , and $80 \%$ RH have similar light absorption to one another. Thus, moderate RH enhances the MAC values by a factor of 1.33 at $365 \mathrm{~nm}$ and further increases in RH have no effect. An overview of toluene-SOA molecular compositions was analyzed by nano-DESI/HRMS (Lin et al., 2015b), and showed that a large number of nitrogen-containing compounds $(\mathrm{CHON})$ were produced under moderate $\mathrm{RH}$ condition (Fig. S3). The difference in molecular compositions suggest that low RH inhibited the formation of nitrogencontaining compounds, which have been shown to be major light absorbers in toluene SOA formed in the presence of $\mathrm{NO}_{x}$ (Nakayama et al., 2013; P. F. Liu et al., 2015; Zhang et al., 2011; Lin et al., 2015b).

We are unable to identify any gas-phase reactions in the toluene photolysis mechanism directly involving water vapor. Thus, we conclude that RH must be affecting particle-phase reactions that enhance chromophore formation. Several studies have investigated the effect of RH on various particle-phase SOA chemistry and optical properties. Song et al. (2013) found that SOA produced from $\alpha$ pinene $+\mathrm{NO}_{x}+\mathrm{O}_{3}$ in the presence of acidic seed aerosols at elevated RH was less light-absorbing than SOA formed under dry conditions, which is opposite of our observations. They suggested that the change in light-absorbing properties might be triggered by evaporation of water, which may have enhanced the acidity of aerosol seeds (Nguyen et al., 2012), thereby promoting oligomerization reactions. Zhong and Jang (2014) investigated the light absorption of $\mathrm{BrC}$ formed from wood burning and observed a faster decay of chromophores at higher $\mathrm{RH}$, which they attributed to the decomposition of chromophores by $\mathrm{H}_{2} \mathrm{O}_{2}$ that is produced by aqueous-phase photooxidation in the presence of elevated water content level. Moderate to high RH may promote 
Table 1. Summary of experiments and experimental conditions described in this work.

\begin{tabular}{lcllll}
\hline Experiment & $\begin{array}{c}\text { Experiment } \\
\text { type }\end{array}$ & VOC & $\begin{array}{l}\text { Initial VOC } \\
\text { concentration } \\
(\mathrm{ppb})\end{array}$ & Initial NO (ppb) & $\begin{array}{l}\mathrm{RH} \\
(\%)\end{array}$ \\
\hline 1 & 1 & isoprene & 359.37 & $<1\left(\mathrm{NO}_{x}\right.$ free) & 30 \\
2 & 1 & $\alpha$-pinene & 22.73 & $<1\left(\mathrm{NO}_{x}\right.$ free) & 30 \\
3 & 1 & TMB & 316.30 & $<1\left(\mathrm{NO}_{x}\right.$ free) & 30 \\
4 & 1 & toluene & 339.92 & $<1\left(\mathrm{NO}_{x}\right.$ free) & 30 \\
5 & 2 & isoprene & 311.45 & $1754.67\left(\right.$ high $\left.\mathrm{NO}_{x}\right)$ & 30 \\
6 & 2 & $\alpha$-pinene & 45.45 & $466.09\left(\right.$ high $\left.\mathrm{NO}_{x}\right)$ & 30 \\
7 & 2 & TMB & 289.94 & $1589.6\left(\right.$ high NO $\left.\mathrm{NO}_{x}\right)$ & 30 \\
8 & 2 & toluene & 317.26 & $1800\left(\right.$ high $\left.\mathrm{NO}_{x}\right)$ & 30 \\
9 & 2 & Isoprene $+\mathrm{TMB}$ & $178.51+123.71$ & $1800\left(\right.$ high $\left.\mathrm{NO}_{x}\right)$ & 30 \\
10 & 2 & Isoprene + toluene & $158.09+106.43$ & $1800\left(\right.$ high $\left.\mathrm{NO}_{x}\right)$ & 30 \\
11 & 3 & TMB & 263.58 & $1500\left(\right.$ high $\left.\mathrm{NO}_{x}\right)$ & 30 \\
12 & 3 & toluene & 339.92 & $1900\left(\right.$ high $\left.\mathrm{NO}_{x}\right)$ & 30 \\
13 & 4 & TMB & 263.58 & $1800\left(\right.$ high $\left.\mathrm{NO}_{x}\right)$ & $<5$ \\
14 & 4 & TMB & 263.58 & $1800\left(\right.$ high $\left.\mathrm{NO}_{x}\right)$ & 50 \\
15 & 4 & TMB & 263.58 & $1800\left(\right.$ high $\left.\mathrm{NO}_{x}\right)$ & 80 \\
16 & 4 & Toluene & 396 & $1800\left(\right.$ high $\left.\mathrm{NO}_{x}\right)$ & $<5$ \\
17 & 4 & Toluene & 300 & $1800\left(\right.$ high $\left.\mathrm{NO}_{x}\right)$ & 50 \\
18 & 4 & Toluene & 339.92 & $1800\left(\right.$ high $\left.\mathrm{NO}_{x}\right)$ & 80 \\
\hline
\end{tabular}

heterogeneous reactions, which aids in the reactive uptake of volatile compounds into aerosols. Cao and Jang (2010) decoupled SOA mass into partitioning and heterogeneous aerosol production in a toluene- $\mathrm{NO}_{x}$ system, and suggested that moderate $\mathrm{RH}$ results in a higher fraction of SOA formed via heterogeneous reactions than low RH conditions. Similar effects might be also pertinent to the toluene SOA. Another possible explanation is that SOA formed under low RH conditions may exist in a viscous, semi-solid, or glassy state due to particle-phase oligomerization reactions (Saukko et al., 2012; Shiraiwa et al., 2013), whereas SOA formed at moderate/high RH would be less viscous. Since only one experiment was conducted under dry condition for each compound it is difficult to draw conclusions, but further investigations are warranted.

\subsection{Effect of photochemical aging on light absorption of aromatic SOA}

Atmospheric aerosols have a wide range of lifetimes, ranging from hours to days (i.e., Wagstrom and Pandis, 2009). Previous studies have observed a decrease in aerosol absorption with aging in $\mathrm{BrC}$ from various sources including biomass burning and SOA formed from aromatics (Forrister et al., 2015; Zhong and Jang, 2011; Lee et al., 2014). We therefore performed several experiments to study the effect of aging on $\mathrm{BrC}$ absorption. Figure 6 shows the MAC values at $365 \mathrm{~nm}$ as a function of photolysis time for toluene and TMB SOA produced in the presence of $\mathrm{NO}_{x}$ at $30 \% \mathrm{RH}$ (complete spectra in the wavelength range of $300-700 \mathrm{~nm}$ are provided as Fig. S4, with values tabulated in Table S3). We observe a

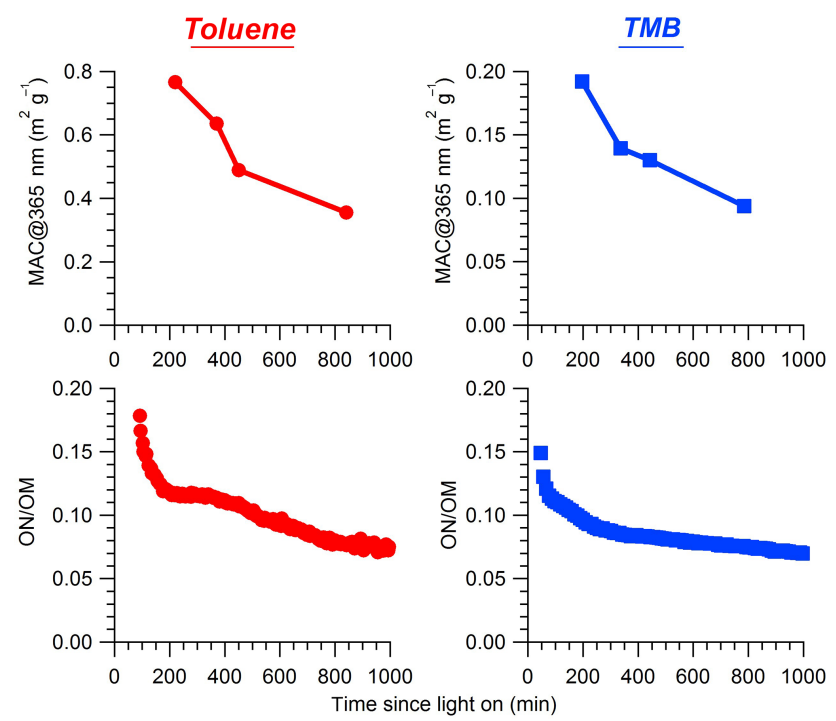

Figure 6. Measurements of the MAC values (at $365 \mathrm{~nm}$ ) of toluene and TMB SOA formed at $30 \% \mathrm{RH}$ in the presence of $\mathrm{NO}_{x}$ as a function of photochemical age (top panels). The bottom panels show the AMS-measured ON-to-OM ratio.

clear decrease in aerosol absorption with aging with MAC values decreasing by $\sim 35 \%$ after $400 \mathrm{~min}$ and $>50 \%$ after $800 \mathrm{~min}$.

Laboratory studies have suggested that photo-bleaching was due to degradation of $\mathrm{BrC}$ chromophores (Lee et al., 2014; Zhong and Jang, 2011, 2014). In our observations, the decrease of MAC with aging is accompanied by a decreas- 


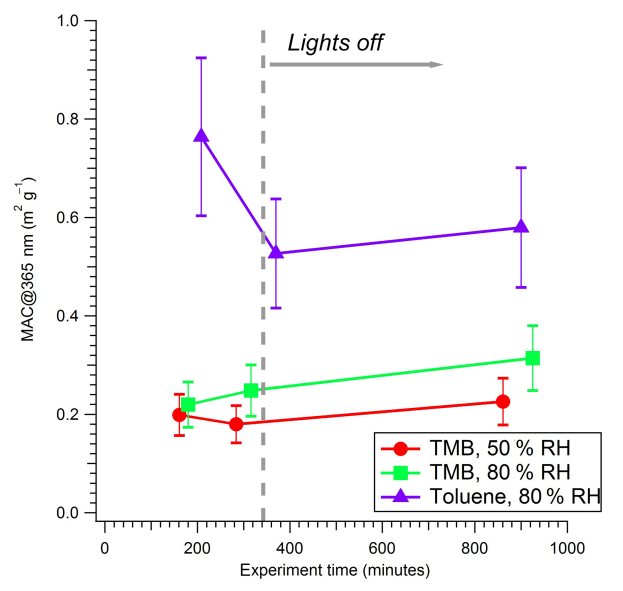

Figure 7. MAC values of aromatic SOA formed under high-NO $\mathrm{NO}_{x}$ conditions and aged in the chamber with the lights off at different RH levels.

ing ON-to-OM ratio, shown in Fig. 6. Here we define the term $\mathrm{ON}$ as the sum of the $\mathrm{NO}, \mathrm{NO}_{2}$, and $\mathrm{C}_{x} \mathrm{H}_{y} \mathrm{O}_{z} \mathrm{~N}_{w}$ families measured by AMS, to represent organic nitrates formed during the experiments. $\mathrm{NO}$ and $\mathrm{NO}_{2}$ come exclusively from organic nitrates in these experiments. Ammonium is below the instrument detection limit, and the ratio of $m / z 30: 46$ (around 5-6) is indicative of organic nitrate, thus ruling out formation of ammonium nitrate (Farmer et al., 2010). Therefore, the decrease in the aerosol ON : OM with time indicates the loss of ON groups (Fig. 6). ON groups have been identified as the strong light absorbers in aromatic SOA formed under high- $\mathrm{NO}_{x}$ conditions; thus, the relative decrease in $\mathrm{ON}$ fraction relative to $\mathrm{OM}$ is consistent with the observed evolution in OA light absorption.

This observed loss of ON could be caused by photolysis and/or hydrolysis of ON groups. Lee et al. (2014) observed a substantial decline in the double bond equivalent (DBE) values upon photolysis of aromatic SOA, and suggested that the decrease in SOA light absorption and chemical composition was due to photolysis. On the other hand, Liu et al. (2012) suggested that particle-phase hydrolysis could substantially reduce $\mathrm{ON}$ group concentration, which they also related to a decrease in $\mathrm{BrC}$ light absorption. To distinguish between the effects from photolysis and hydrolysis, SOA was allowed to age in the chamber with UV lights off but at elevated $\mathrm{RH}$ in several experiments. Shown in Fig. 7, the MAC values of toluene and TMB SOA are approximately constant with aging despite the elevated RH. Therefore, we conclude that decrease in MAC values are driven primarily by photolysis (i.e., photobleaching), which is correlated with loss of $\mathrm{ON}$ groups that have been shown in many studies, including our companion study, to be $\mathrm{BrC}$ chromophores (Lin et al., 2015b; P. F. Liu et al., 2015; Zhang et al., 2013). The effect of RH is less clear, with the dark experiments suggesting the net effect of water-related processes, such as hydrolysis and oligomer-
Table 2. Derived imaginary part of refractive index $(k)$ of brown carbon formed from various VOC precursors at $365 \mathrm{~nm}$. Tabulated values are $k \times 10^{3}$.

\begin{tabular}{lll}
\hline & $\mathrm{NO}_{x}$ free & High $\mathrm{NO}_{x}$ \\
\hline Isoprene & 0.029 & 0.196 \\
$\alpha$-pinene & 0 & 1.15 \\
TMB & 0.967 & $6.028-9.899$ \\
Toluene & 0.461 & $19.48-46.87$ \\
\hline
\end{tabular}

ization, is either negligible or tends to slightly enhance $\mathrm{BrC}$ light absorption, while comparison of experiments with and without RH (Sect. 3.3) suggests moderate RH enhances the SOA MAC values.

\subsection{Imaginary refractive indices}

So far, our discussion focused on mass-normalized absorption based on solution measurements, which is not directly relatable to light absorption by aerosol particles. Therefore, we derive the imaginary refractive index, $k$, from spectroscopic data, which can be incorporated into climate models. The $k$ value is derived using Eq. (2):

$k=\frac{\rho_{p} \lambda \cdot \operatorname{Abs}(\lambda)}{4 \pi \cdot \mathrm{OM}}=\frac{\rho_{p} \lambda}{4 \pi} \operatorname{MAC}(\lambda)$,

where $\operatorname{Abs}(\lambda)$ is the solution absorption at a given wavelength, $\mathrm{OM}$ is the organic mass extracted in solution, and $\rho_{p}$ is the density of organic aerosols. The density of organic aerosols was calculated by comparing the volume-weighted mobility size measured by SMPS and the mass-weighted aerodynamic size distribution measured by AMS (DeCarlo et al., 2004). A density of $1.25 \pm 0.3 \mathrm{~g} \mathrm{~cm}^{-3}$ was obtained for SOA produced under $\mathrm{NO}_{x}$-free conditions, while a density of $1.41 \pm 0.2 \mathrm{~g} \mathrm{~cm}^{-3}$ was estimated for SOA produced in high- $\mathrm{NO}_{x}$ experiments. Those density values were employed in Eq. (2) to estimate $k$ values at $365 \mathrm{~nm}$ for various types of SOA, which are summarized in Table 2 ( $k$ values for the $300-700 \mathrm{~nm}$ range are listed in Table S4).

Although $\alpha$-pinene and isoprene have large contributions to the global SOA budget, they were shown to produce SOA with very small light absorption coefficients under the photochemical conditions we investigated, which agrees with literature data (i.e., Nakayama et al., 2010; Lang-Yona et al., 2010). The SOA compounds produced are dominated by carbonyl, carboxyl, and hydroxyl functional groups, which do not have strong electronic transitions in the UV-Vis range. As a result, those biogenic SOA particles are expected to have a mostly cooling effect on global radiative balance. However, studies have shown that biogenic SOA can be converted into $\mathrm{BrC}$ via reactions with dissolved ammonia (Updyke et al., 2012; Laskin et al., 2014), or by monoterpene SOA formed from nighttime reactions with $\mathrm{NO}_{3}$ radical (Washenfelder et al., 2015). Furthermore, it has been demon- 
strated that reactive uptake of IEPOX into acidic aerosols produce BrC (Y.-H. Lin et al., 2014), which may have substantial impacts on specific regions with elevated ammonia levels and/or active IEPOX chemistry.

In the present study, the SOA generated from the photooxidation of aromatic VOC precursors, particularly toluene, were found to have significant absorption in the UV-Vis range when formed in the presence of $\mathrm{NO}_{x}$. Toluene SOA formed under high- $\mathrm{NO}_{x}$ conditions has a $k$ value ranging from 0.019 to 0.047 at $365 \mathrm{~nm}$, and $0.011-0.033$ at $405 \mathrm{~nm}$. Shown in Fig. 3b, the $k$ values are in good agreement with the measurement by Nakayama et al. (2010), where reported $k$ values were 0.047 at $355 \mathrm{~nm}$ and 0.007 at $532 \mathrm{~nm}$. The $k$ values reported by Zhong and Jang (2011) and P. F. Liu et al. (2015) are close to the lower limit from this work, the former reported a $k$ value of 0.0214 at $350 \mathrm{~nm}$, and the latter reported a range of $0.022-0.033$ at $320 \mathrm{~nm}$. However, the $k$ values derived in this work are substantially higher than those in Nakayama et al. (2013), which reported $k$ values ranging from 0.0018 to 0.0072 at $405 \mathrm{~nm}$. A possible explanation is the difference in $\mathrm{NO}_{x}$ levels among the experiments; Zhong and Jang (2011) and Nakayama et al. (2013) studies were conducted at $\mathrm{NO}_{x}$ levels lower than $1 \mathrm{ppmv}$, which are lower than employed in our study. Nakayama et al. (2013) has reported that light absorption of SOA has a dependence on $\mathrm{NO}_{x}$, that MAC increases with $\mathrm{NO}_{x}$, which likely also explains the higher $k$ values reported by earlier work from the same group (Nakayama et al., 2010). Another potentially important difference among the experiments is the RH, with Nakayama 2013 and the Liu studies conducted under dry conditions (Nakayama et al., 2013; P. F. Liu et al., 2015). From what we have observed, moderate RH could enhance the light absorption of $\mathrm{BrC}$.

\section{Conclusions and atmospheric implications}

Among ambient studies reporting $\mathrm{BrC}$ light absorption, high MAC values are almost exclusively reported for aerosols attributed to biomass burning (Kirchstetter et al., 2004; Hoffer et al., 2006; Alexander et al., 2008; Dinar et al., 2008; Chakrabarty et al., 2010; Lack et al., 2013), and the limited number of models that include $\mathrm{BrC}$ generally use biomass burning aerosol optical properties as high-absorption references (G. Lin et al., 2014; Feng et al., 2013). Our results suggest that organic aerosols formed from certain anthropogenic VOC precursors also display efficient light absorption. Specifically, the MAC values obtained from the toluene + high- $\mathrm{NO}_{x}$ experiment were comparable to that of fulvic acid, which has been used as model compounds for biomass burning HULIS (Dinar et al., 2006; Brooks et al., 2004; Chan and Chan, 2003; Fuzzi et al., 2001; Samburova et al., 2005). The results suggest that in addition to $\mathrm{BrC}$ from biomass burning, the photooxidation of anthropogenic pre- cursors can also have significant impacts on light absorption at wavelengths that drive photochemical reactions.

$\mathrm{BrC}$ observed in urban environments has large variations in reported MAC values, and our mixed-precursor experiments may provide some explanations for the observed variation. From our measurements, SOA formed from mixtures of isoprene + aromatic VOC have lower MAC values than those formed from the pure aromatics, suggesting that isoprene photooxidation products dilute light-absorbing compounds. Therefore, it is possible that some of the variance in $\mathrm{BrC}$ properties between urban sites can be explained by the presence or absence of biogenic emissions. In addition, our results suggested that $\mathrm{NO}_{x}$ concentration, $\mathrm{RH}$ level, and photolysis time have considerable influences on the formation and decay of light-absorbing compounds. Similar lightabsorbing compounds have been identified in certain SOA samples originating from biomass burning (Desyaterik et al., 2013; Iinuma et al., 2010); since substantial variations in SOA formation in biomass burning plumes have been observed both chemically and physically due to fuel types and fire aging conditions (Hennigan et al., 2011), we cannot simply assume similar effects of those parameters on SOA produced from biomass burning emissions. Thus, the result suggests that we should revisit how SOA is treated in climate models, especially in urban areas. Several current regional and global models include $\mathrm{NO}_{x}$-dependent $\mathrm{SOA}$ yield (Lane et al., 2008; Farina et al., 2010; Ahmadov et al., 2012); accurately parameterizing $\mathrm{BrC}$ formation from $\mathrm{SOA}$ will require a similar strategy.

\section{Data availability}

All data are available upon request to the authors.

\section{The Supplement related to this article is available online at doi:10.5194/acp-16-12815-2016-supplement.}

\begin{abstract}
Acknowledgements. Authors acknowledge support by the Laboratory Directed Research and Development funds of Pacific Northwest National Laboratory (PNNL). A portion of this study was performed at the William R. Wiley Environmental Molecular Sciences Laboratory, a national scientific user facility sponsored by the DOE's Office of Biological and Environmental Research and located at PNNL. PNNL is operated for the US Department of Energy by Battelle Memorial Institute under contract no. DEAC06-76RLO 1830.
\end{abstract}

Edited by: V. F. McNeill

Reviewed by: two anonymous referees 


\section{References}

Ahmadov, R., McKeen, S. A., Robinson, A. L., Bahreini, R., Middlebrook, A. M., de Gouw, J. A., Meagher, J., Hsie, E. Y., Edgerton, E., Shaw, S., and Trainer, M.: A volatility basis set model for summertime secondary organic aerosols over the eastern United States in 2006, J. Geophys. Res.-Atmos., 117, D06301, doi:10.1029/2011JD016831, 2012.

Alexander, D. T. L., Crozier, P. A., and Anderson, J. R.: Brown carbon spheres in East Asian outflow and their optical properties, Science, 321, 833-836, doi:10.1126/science.1155296, 2008.

Andreae, M. O. and Gelencsér, A.: Black carbon or brown carbon? The nature of light-absorbing carbonaceous aerosols, Atmos. Chem. Phys., 6, 3131-3148, doi:10.5194/acp-6-3131-2006, 2006.

Bikkina, S. and Sarin, M. M.: Light absorbing organic aerosols (brown carbon) over the tropical Indian Ocean: impact of biomass burning emissions, Environ. Res. Lett., 8, 044042, doi:10.1088/1748-9326/8/4/044042, 2013.

Bond, T. C., Doherty, S. J., Fahey, D. W., Forster, P. M., Berntsen, T., DeAngelo, B. J., Flanner, M. G., Ghan, S., Kärcher, B., Koch, D., Kinne, S., Kondo, Y., Quinn, P. K., Sarofim, M. C., Schultz, M. G., Schulz, M., Venkataraman, C., Zhang, H., Zhang, S., Bellouin, N., Guttikunda, S. K., Hopke, P. K., Jacobson, M. Z., Kaiser, J. W., Klimont, Z., Lohmann, U., Schwarz, J. P., Shindell, D., Storelvmo, T., Warren, S. G., and Zender, C. S.: Bounding the role of black carbon in the climate system: A scientific assessment, J. Geophys. Res.-Atmos., 118, 5380-5552, doi:10.1002/jgrd.50171, 2013.

Bones, D. L., Henricksen, D. K., Mang, S. A., Gonsior, M., Bateman, A. P., Nguyen, T. B., Cooper, W. J., and Nizkorodov, S. A.: Appearance of strong absorbers and fluorophores in limonene$\mathrm{O} 3$ secondary organic aerosol due to $\mathrm{NH}_{4}^{+}$-mediated chemical aging over long time scales, J. Geophys. Res.-Atmos., 115, D05203, doi:10.1029/2009JD012864, 2010.

Brooks, S. D., DeMott, P. J., and Kreidenweis, S. M.: Water uptake by particles containing humic materials and mixtures of humic materials with ammonium sulfate, Atmos. Environ., 38, 18591868, doi:10.1016/j.atmosenv.2004.01.009, 2004.

Cao, G. and Jang, M.: An SOA Model for Toluene Oxidation in the Presence of Inorganic Aerosols, Environ. Sci. Technol., 44, 727-733, doi:10.1021/es901682r, 2010.

Chakrabarty, R. K., Moosmüller, H., Chen, L. W. A., Lewis, K., Arnott, W. P., Mazzoleni, C., Dubey, M. K., Wold, C. E., Hao, W. M., and Kreidenweis, S. M.: Brown carbon in tar balls from smoldering biomass combustion, Atmos. Chem. Phys., 10, 63636370, doi:10.5194/acp-10-6363-2010, 2010.

Chan, M. N. and Chan, C. K.: Hygroscopic Properties of Two Model Humic-like Substances and Their Mixtures with Inorganics of Atmospheric Importance, Environ. Sci. Technol., 37, 5109-5115, doi:10.1021/es034272o, 2003.

Chen, Y. and Bond, T. C.: Light absorption by organic carbon from wood combustion, Atmos. Chem. Phys., 10, 1773-1787, doi:10.5194/acp-10-1773-2010, 2010.

Chung, C. E., Ramanathan, V., and Decremer, D.: Observationally constrained estimates of carbonaceous aerosol radiative forcing, P. Natl. Acad. Sci. USA, 109, 11624-11629, doi:10.1073/pnas.1203707109, 2012.

DeCarlo, P. F., Slowik, J. G., Worsnop, D. R., Davidovits, P., and Jimenez, J. L.: Particle Morphology and Density Characteriza- tion by Combined Mobility and Aerodynamic Diameter Measurements. Part 1: Theory, Aerosol Sci. Tech., 38, 1185-1205, doi:10.1080/027868290903907, 2004.

DeCarlo, P. F., Kimmel, J. R., Trimborn, A., Northway, M. J., Jayne, J. T., Aiken, A. C., Gonin, M., Fuhrer, K., Horvath, T., Docherty, K. S., Worsnop, D. R., and Jimenez, J. L.: Field-Deployable, High-Resolution, Time-of-Flight Aerosol Mass Spectrometer, Anal. Chem., 78, 8281-8289, doi:10.1021/ac061249n, 2006.

De Haan, D. O. D., Corrigan, A. L., Smith, K. W., Stroik, D. R., Turley, J. J., Lee, F. E., Tolbert, M. A., Jimenez, J. L., Cordova, K. E., and Ferrell, G. R.: Secondary Organic Aerosol-Forming Reactions of Glyoxal with Amino Acids, Environ. Sci. Technol., 43, 2818-2824, doi:10.1021/es803534f, 2009.

Desyaterik, Y., Sun, Y., Shen, X. H., Lee, T. Y., Wang, X. F., Wang, T., and Collett, J. L.: Speciation of "brown" carbon in cloud water impacted by agricultural biomass burning in eastern China, J. Geophys. Res.-Atmos., 118, 7389-7399, doi:10.1002/Jgrd.50561, 2013.

Dinar, E., Mentel, T. F., and Rudich, Y.: The density of humic acids and humic like substances (HULIS) from fresh and aged wood burning and pollution aerosol particles, Atmos. Chem. Phys., 6, 5213-5224, doi:10.5194/acp-6-5213-2006, 2006.

Dinar, E., Abo Riziq, A., Spindler, C., Erlick, C., Kiss, G., and Rudich, Y.: The complex refractive index of atmospheric and model humic-like substances (HULIS) retrieved by a cavity ring down aerosol spectrometer (CRD-AS), Faraday Discuss., 137, 279-295, doi:10.1039/B703111D, 2008.

Du, Z., He, K., Cheng, Y., Duan, F., Ma, Y., Liu, J., Zhang, X., Zheng, M., and Weber, R.: A yearlong study of water-soluble organic carbon in Beijing II: Light absorption properties, Atmos. Environ., 89, 235-241, doi:10.1016/j.atmosenv.2014.02.022, 2014.

Duarte, R. M. B. O., Pio, C. A., and Duarte, A. C.: Spectroscopic study of the water-soluble organic matter isolated from atmospheric aerosols collected under different atmospheric conditions, Anal. Chim. Ac., 530, 7-14, doi:10.1016/j.aca.2004.08.049, 2005.

Farina, S. C., Adams, P. J., and Pandis, S. N.: Modeling global secondary organic aerosol formation and processing with the volatility basis set: Implications for anthropogenic secondary organic aerosol, J. Geophys. Res.-Atmos., 115, D09202, doi:10.1029/2009JD013046, 2010.

Farmer, D. K., Matsunaga, A., Docherty, K. S., Surratt, J. D., Seinfeld, J. H., Ziemann, P. J., and Jimenez, J. L.: Response of an aerosol mass spectrometer to organonitrates and organosulfates and implications for atmospheric chemistry, P. Natl. Acad. Sci. USA, 107, 6670-6675, doi:10.1073/pnas.0912340107, 2010.

Feng, Y., Ramanathan, V., and Kotamarthi, V. R.: Brown carbon: a significant atmospheric absorber of solar radiation?, Atmos. Chem. Phys., 13, 8607-8621, doi:10.5194/acp-13-8607-2013, 2013.

Forrister, H., Liu, J., Scheuer, E., Dibb, J., Ziemba, L., Thornhill, K. L., Anderson, B., Diskin, G., Perring, A. E., Schwarz, J. P., Campuzano-Jost, P., Day, D. A., Palm, B. B., Jimenez, J. L., Nenes, A., and Weber, R. J.: Evolution of Brown Carbon in Wildfire Plumes, Geophys. Res. Lett., 42, 4623-4630, doi:10.1002/2015GL063897, 2015.

Fuzzi, S., Decesari, S., Facchini, M. C., Matta, E., Mircea, M., and Tagliavini, E.: A simplified model of the water soluble or- 
ganic component of atmospheric aerosols, Geophys. Res. Lett., 28, 4079-4082, doi:10.1029/2001GL013418, 2001.

Galloway, M. M., Chhabra, P. S., Chan, A. W. H., Surratt, J. D., Flagan, R. C., Seinfeld, J. H., and Keutsch, F. N.: Glyoxal uptake on ammonium sulphate seed aerosol: reaction products and reversibility of uptake under dark and irradiated conditions, Atmos. Chem. Phys., 9, 3331-3345, doi:10.5194/acp-9-3331-2009, 2009.

Guenther, A., Karl, T., Harley, P., Wiedinmyer, C., Palmer, P. I., and Geron, C.: Estimates of global terrestrial isoprene emissions using MEGAN (Model of Emissions of Gases and Aerosols from Nature), Atmos. Chem. Phys., 6, 3181-3210, doi:10.5194/acp-63181-2006, 2006.

Guenther, A. B., Jiang, X., Heald, C. L., Sakulyanontvittaya, T., Duhl, T., Emmons, L. K., and Wang, X.: The Model of Emissions of Gases and Aerosols from Nature version 2.1 (MEGAN2.1): an extended and updated framework for modeling biogenic emissions, Geosci. Model Dev., 5, 1471-1492, doi:10.5194/gmd-51471-2012, 2012.

Hecobian, A., Zhang, X., Zheng, M., Frank, N., Edgerton, E. S., and Weber, R. J.: Water-Soluble Organic Aerosol material and the light-absorption characteristics of aqueous extracts measured over the Southeastern United States, Atmos. Chem. Phys., 10, 5965-5977, doi:10.5194/acp-10-5965-2010, 2010.

Hennigan, C. J., Miracolo, M. A., Engelhart, G. J., May, A. A., Presto, A. A., Lee, T., Sullivan, A. P., McMeeking, G. R., Coe, H., Wold, C. E., Hao, W. M., Gilman, J. B., Kuster, W. C., de Gouw, J., Schichtel, B. A., Collett Jr., J. L., Kreidenweis, S. M., and Robinson, A. L.: Chemical and physical transformations of organic aerosol from the photo-oxidation of open biomass burning emissions in an environmental chamber, Atmos. Chem. Phys., 11, 7669-7686, doi:10.5194/acp-11-7669-2011, 2011.

Henry, K. M. and Donahue, N. M.: Photochemical Aging of $\alpha$-Pinene Secondary Organic Aerosol: Effects of $\mathrm{OH}$ Radical Sources and Photolysis, J. Phys. Chem. A, 116, 5932-5940, doi:10.1021/jp210288s, 2012.

Henze, D. K., Seinfeld, J. H., Ng, N. L., Kroll, J. H., Fu, T. M., Jacob, D. J., and Heald, C. L.: Global modeling of secondary organic aerosol formation from aromatic hydrocarbons: highvs. low-yield pathways, Atmos. Chem. Phys., 8, 2405-2420, doi:10.5194/acp-8-2405-2008, 2008.

Hoffer, A., Gelencsér, A., Guyon, P., Kiss, G., Schmid, O., Frank, G. P., Artaxo, P., and Andreae, M. O.: Optical properties of humic-like substances (HULIS) in biomass-burning aerosols, Atmos. Chem. Phys., 6, 3563-3570, doi:10.5194/acp-6-3563-2006, 2006.

Iinuma, Y., Böge, O., Gräfe, R., and Herrmann, H.: MethylNitrocatechols: Atmospheric Tracer Compounds for Biomass Burning Secondary Organic Aerosols, Environ. Sci. Technol., 44, 8453-8459, doi:10.1021/es102938a, 2010.

IPCC: Climate Change: The Physical Science Basis, Contribution of Working Group I to the UN IPCC's 5th Assessment Report, Cambridge University Press, New York, USA, 2013.

Jaoui, M., Edney, E. O., Kleindienst, T. E., Lewandowski, M., Offenberg, J. H., Surratt, J. D., and Seinfeld, J. H.: Formation of secondary organic aerosol from irradiated $\alpha$-pinene/toluene/ $\mathrm{NO}_{x}$ mixtures and the effect of isoprene and sulfur dioxide, J. Geophys. Res.-Atmos., 113, D09303, doi:10.1029/2007JD009426, 2008.
Kampf, C. J., Jakob, R., and Hoffmann, T.: Identification and characterization of aging products in the glyoxal/ammonium sulfate system - implications for light-absorbing material in atmospheric aerosols, Atmos. Chem. Phys., 12, 6323-6333, doi:10.5194/acp-12-6323-2012, 2012.

Kieber, R., Whitehead, R., Reid, S., Willey, J., and Seaton, P.: Chromophoric Dissolved Organic Matter (CDOM) In Rainwater, Southeastern North Carolina, USA, J. Atmos. Chem., 54, 21-41, doi:10.1007/s10874-005-9008-4, 2006.

Kirchstetter, T. W. and Thatcher, T. L.: Contribution of organic carbon to wood smoke particulate matter absorption of solar radiation, Atmos. Chem. Phys., 12, 6067-6072, doi:10.5194/acp-126067-2012, 2012.

Kirchstetter, T. W., Novakov, T., and Hobbs, P. V.: Evidence that the spectral dependence of light absorption by aerosols is affected by organic carbon, J. Geophys. Res.-Atmos., 109, D21208, doi:10.1029/2004JD004999, 2004.

Kleindienst, T. E., Conver, T. S., McIver, C. D., and Edney, E. O.: Determination of Secondary Organic Aerosol Products from the Photooxidation of Toluene and their Implications in Ambient $\mathrm{PM}_{2.5}$, J. Atmos. Chem., 47, 79-100, doi:10.1023/B:JOCH.0000012305.94498.28, 2004.

Krechmer, J. E., Coggon, M. M., Massoli, P., Nguyen, T. B., Crounse, J. D., Hu, W., Day, D. A., Tyndall, G. S., Henze, D. K., Rivera-Rios, J. C., Nowak, J. B., Kimmel, J. R., Mauldin, R. L., Stark, H., Jayne, J. T., Sipilä, M., Junninen, H., St. Clair, J. M., Zhang, X., Feiner, P. A., Zhang, L., Miller, D. O., Brune, W. H., Keutsch, F. N., Wennberg, P. O., Seinfeld, J. H., Worsnop, D. R., Jimenez, J. L., and Canagaratna, M. R.: Formation of Low Volatility Organic Compounds and Secondary Organic Aerosol from Isoprene Hydroxyhydroperoxide Low-NO Oxidation, Environ. Sci. Technol., 49, 10330-10339, doi:10.1021/acs.est.5b02031, 2015.

Kuhn, H.: A Quantum-Mechanical Theory of Light Absorption of Organic Dyes and Similar Compounds, J. Chem. Phys., 17, 1198-1212, doi:10.1063/1.1747143, 1949.

Lack, D. A., Langridge, J. M., Bahreini, R., Cappa, C. D., Middlebrook, A. M., and Schwarz, J. P.: Brown carbon and internal mixing in biomass burning particles, P. Natl. Acad. Sci. USA, 109, 14802-14807, doi:10.1073/pnas.1206575109, 2012.

Lack, D. A., Bahreni, R., Langridge, J. M., Gilman, J. B., and Middlebrook, A. M.: Brown carbon absorption linked to organic mass tracers in biomass burning particles, Atmos. Chem. Phys., 13, 2415-2422, doi:10.5194/acp-13-2415-2013, 2013.

Lambe, A. T., Cappa, C. D., Massoli, P., Onasch, T. B., Forestieri, S. D., Martin, A. T., Cummings, M. J., Croasdale, D. R., Brune, W. H., Worsnop, D. R., and Davidovits, P.: Relationship between Oxidation Level and Optical Properties of Secondary Organic Aerosol, Environ. Sci. Technol., 47, 6349-6357, doi:10.1021/es401043j, 2013.

Lane, T. E., Donahue, N. M., and Pandis, S. N.: Effect of $\mathrm{NO}_{x}$ on Secondary Organic Aerosol Concentrations, Environ. Sci. Technol., 42, 6022-6027, doi:10.1021/es703225a, 2008.

Lang-Yona, N., Abo-Riziq, A., Erlick, C., Segre, E., Trainic, M., and Rudich, Y.: Interaction of internally mixed aerosols with light, Phys. Chem. Chem. Phys., 12, 21-31, doi:10.1039/B913176K, 2010. 
Laskin, A., Laskin, J., and Nizkorodov, S. A.: Chemistry of Atmospheric Brown Carbon, Chem. Rev., 115, 4335-4382, doi:10.1021/cr5006167, 2015.

Laskin, J., Laskin, A., Nizkorodov, S. A., Roach, P., Eckert, P., Gilles, M. K., Wang, B., Lee, H. J., and Hu, Q.: Molecular Selectivity of Brown Carbon Chromophores, Environ. Sci. Technol., 48, 12047-12055, doi:10.1021/es503432r, 2014.

Lee, H. J., Aiona, P. K., Laskin, A., Laskin, J., and Nizkorodov, S. A.: Effect of Solar Radiation on the Optical Properties and Molecular Composition of Laboratory Proxies of Atmospheric Brown Carbon, Environ. Sci. Technol., 48, 1021710226, doi:10.1021/es502515r, 2014.

Leighton, P. A.: Photochemistry of Air Pollution, Academic, San Diego, California, 1961.

Limbeck, A., Kulmala, M., and Puxbaum, H.: Secondary organic aerosol formation in the atmosphere via heterogeneous reaction of gaseous isoprene on acidic particles, Geophys. Res. Lett., 30, 1996, doi:10.1029/2003GL017738, 2003.

Lin, G., Penner, J. E., Flanner, M. G., Sillman, S., Xu, L., and Zhou, C.: Radiative forcing of organic aerosol in the atmosphere and on snow: Effects of SOA and brown carbon, J. Geophys. Res.Atmos., 119, 7453-7476, doi:10.1002/2013JD021186, 2014.

Lin, P., Laskin, J., Nizkorodov, S. A., and Laskin, A.: Revealing Brown Carbon Chromophores Produced in Reactions of Methylglyoxal with Ammonium Sulfate, Environ. Sci. Technol., 49, 14257-14266, doi:10.1021/acs.est.5b03608, 2015a.

Lin, P., Liu, J., Shilling, J. E., Kathmann, S. M., Laskin, J., and Laskin, A.: Molecular characterization of brown carbon $(\mathrm{BrC})$ chromophores in secondary organic aerosol generated from photo-oxidation of toluene, Phys. Chem. Chem. Phys., 17, 23312-23325, doi:10.1039/C5CP02563J, 2015b.

Lin, Y.-H., Budisulistiorini, S. H., Chu, K., Siejack, R. A., Zhang, H., Riva, M., Zhang, Z., Gold, A., Kautzman, K. E., and Surratt, J. D.: Light-Absorbing Oligomer Formation in Secondary Organic Aerosol from Reactive Uptake of Isoprene Epoxydiols, Environ. Sci. Technol., 48, 12012-12021, doi:10.1021/es503142b, 2014.

Liu, J., Bergin, M., Guo, H., King, L., Kotra, N., Edgerton, E., and Weber, R. J.: Size-resolved measurements of brown carbon in water and methanol extracts and estimates of their contribution to ambient fine-particle light absorption, Atmos. Chem. Phys., 13, 12389-12404, doi:10.5194/acp-13-12389-2013, 2013.

Liu, J., Scheuer, E., Dibb, J., Ziemba, L. D., Thornhill, K. L., Anderson, B. E., Wisthaler, A., Mikoviny, T., Devi, J. J., Bergin, M., and Weber, R. J.: Brown carbon in the continental troposphere, Geophys. Res. Lett., 41, 2191-2195, doi:10.1002/2013GL058976, 2014.

Liu, J., Scheuer, E., Dibb, J., Diskin, G. S., Ziemba, L. D., Thornhill, K. L., Anderson, B. E., Wisthaler, A., Mikoviny, T., Devi, J. J., Bergin, M., Perring, A. E., Markovic, M. Z., Schwarz, J. P., Campuzano-Jost, P., Day, D. A., Jimenez, J. L., and Weber, R. J.: Brown carbon aerosol in the North American continental troposphere: sources, abundance, and radiative forcing, Atmos. Chem. Phys., 15, 7841-7858, doi:10.5194/acp-15-7841-2015, 2015.

Liu, P. F., Abdelmalki, N., Hung, H. M., Wang, Y., Brune, W. H., and Martin, S. T.: Ultraviolet and visible complex refractive indices of secondary organic material produced by photooxidation of the aromatic compounds toluene and $m$-xylene, Atmos. Chem. Phys., 15, 1435-1446, doi:10.5194/acp-15-1435-2015, 2015.
Liu, S., Shilling, J. E., Song, C., Hiranuma, N., Zaveri, R. A., and Russell, L. M.: Hydrolysis of Organonitrate Functional Groups in Aerosol Particles, Aerosol Sci. Tech., 46, 1359-1369, doi:10.1080/02786826.2012.716175, 2012.

Lukács, H., Gelencsér, A., Hammer, S., Puxbaum, H., Pio, C., Legrand, M., Kasper-Giebl, A., Handler, M., Limbeck, A., Simpson, D., and Preunkert, S.: Seasonal trends and possible sources of brown carbon based on 2-year aerosol measurements at six sites in Europe, J. Geophys. Res.-Atmos., 112, D23S18, doi:10.1029/2006JD008151, 2007.

Mohr, C., Lopez-Hilfiker, F. D., Zotter, P., Prévôt, A. S. H., Xu, L., Ng, N. L., Herndon, S. C., Williams, L. R., Franklin, J. P., Zahniser, M. S., Worsnop, D. R., Knighton, W. B., Aiken, A. C., Gorkowski, K. J., Dubey, M. K., Allan, J. D., and Thornton, J. A.: Contribution of Nitrated Phenols to Wood Burning Brown Carbon Light Absorption in Detling, United Kingdom during Winter Time, Environ. Sci. Technol., 47, 6316-6324, doi:10.1021/es400683v, 2013.

Moise, T., Flores, J. M., and Rudich, Y.: Optical Properties of Secondary Organic Aerosols and Their Changes by Chemical Processes, Chem. Rev., 115, 4400-4439, doi:10.1021/cr5005259, 2015.

Nakayama, T., Matsumi, Y., Sato, K., Imamura, T., Yamazaki, A., and Uchiyama, A.: Laboratory studies on optical properties of secondary organic aerosols generated during the photooxidation of toluene and the ozonolysis of $\alpha$-pinene, J. Geophys. Res.Atmos., 115, D24204, doi:10.1029/2010JD014387, 2010.

Nakayama, T., Sato, K., Matsumi, Y., Imamura, T., Yamazaki, A., and Uchiyama, A.: Wavelength and $\mathrm{NO}_{x}$ dependent complex refractive index of SOAs generated from the photooxidation of toluene, Atmos. Chem. Phys., 13, 531-545, doi:10.5194/acp-13531-2013, 2013.

Ng, N. L., Kroll, J. H., Chan, A. W. H., Chhabra, P. S., Flagan, R. C., and Seinfeld, J. H.: Secondary organic aerosol formation from m-xylene, toluene, and benzene, Atmos. Chem. Phys., 7, 3909-3922, doi:10.5194/acp-7-3909-2007, 2007.

Nguyen, T. B., Laskin, J., Laskin, A., and Nizkorodov, S. A.: Nitrogen-Containing Organic Compounds and Oligomers in Secondary Organic Aerosol Formed by Photooxidation of Isoprene, Environ. Sci. Technol., 45, 6908-6918, doi:10.1021/Es201611n, 2011.

Nguyen, T. B., Lee, P. B., Updyke, K. M., Bones, D. L., Laskin, J., Laskin, A., and Nizkorodov, S. A.: Formation of nitrogenand sulfur-containing light-absorbing compounds accelerated by evaporation of water from secondary organic aerosols, J. Geophys. Res.-Atmos., 117, D01207, doi:10.1029/2011JD016944, 2012.

Nguyen, T. B., Laskin, A., Laskin, J., and Nizkorodov, S. A.: Brown carbon formation from ketoaldehydes of biogenic monoterpenes, Faraday Discuss., 165, 473-494, doi:10.1039/C3FD00036B, 2013.

Odum, J. R., Hoffmann, T., Bowman, F., Collins, D., Flagan, R. C., and Seinfeld, J. H.: Gas/Particle Partitioning and Secondary Organic Aerosol Yields, Environ. Sci. Technol., 30, 2580-2585, doi:10.1021/es950943+, 1996.

Pankow, J. F.: An absorption model of gas/particle partitioning of organic compounds in the atmosphere, Atmos. Environ., 28, 185-188, doi:10.1016/1352-2310(94)90093-0, 1994. 
Petzold, A., Ogren, J. A., Fiebig, M., Laj, P., Li, S. M., Baltensperger, U., Holzer-Popp, T., Kinne, S., Pappalardo, G., Sugimoto, N., Wehrli, C., Wiedensohler, A., and Zhang, X. Y.: Recommendations for reporting "black carbon" measurements, Atmos. Chem. Phys., 13, 8365-8379, doi:10.5194/acp-13-83652013, 2013.

Powelson, M. H., Espelien, B. M., Hawkins, L. N., Galloway, M. M., and De Haan, D. O.: Brown Carbon Formation by Aqueous-Phase Carbonyl Compound Reactions with Amines and Ammonium Sulfate, Environ. Sci. Technol., 48, 985-993, doi:10.1021/Es4038325, 2014.

Presto, A. A. and Donahue, N. M.: Investigation of $\alpha$ Pinene + Ozone Secondary Organic Aerosol Formation at Low Total Aerosol Mass, Environ. Sci. Technol., 40, 3536-3543, doi:10.1021/es052203z, 2006.

Samburova, V., Zenobi, R., and Kalberer, M.: Characterization of high molecular weight compounds in urban atmospheric particles, Atmos. Chem. Phys., 5, 2163-2170, doi:10.5194/acp-52163-2005, 2005.

Sareen, N., Schwier, A. N., Shapiro, E. L., Mitroo, D., and McNeill, V. F.: Secondary organic material formed by methylglyoxal in aqueous aerosol mimics, Atmos. Chem. Phys., 10, 997-1016, doi:10.5194/acp-10-997-2010, 2010.

Sato, K., Takami, A., Kato, Y., Seta, T., Fujitani, Y., Hikida, T., Shimono, A., and Imamura, T.: AMS and LC/MS analyses of SOA from the photooxidation of benzene and 1,3,5-trimethylbenzene in the presence of $\mathrm{NO}_{x}$ : effects of chemical structure on SOA aging, Atmos. Chem. Phys., 12, 4667-4682, doi:10.5194/acp-124667-2012, 2012.

Saukko, E., Lambe, A. T., Massoli, P., Koop, T., Wright, J. P., Croasdale, D. R., Pedernera, D. A., Onasch, T. B., Laaksonen, A., Davidovits, P., Worsnop, D. R., and Virtanen, A.: Humiditydependent phase state of SOA particles from biogenic and anthropogenic precursors, Atmos. Chem. Phys., 12, 7517-7529, doi:10.5194/acp-12-7517-2012, 2012.

Shapiro, E. L., Szprengiel, J., Sareen, N., Jen, C. N., Giordano, M. R., and McNeill, V. F.: Light-absorbing secondary organic material formed by glyoxal in aqueous aerosol mimics, Atmos. Chem. Phys., 9, 2289-2300, doi:10.5194/acp-9-2289-2009, 2009.

Shiraiwa, M., Zuend, A., Bertram, A. K., and Seinfeld, J. H.: Gasparticle partitioning of atmospheric aerosols: interplay of physical state, non-ideal mixing and morphology, Phys. Chem. Chem. Phys., 15, 11441-11453, doi:10.1039/C3CP51595H, 2013.

Song, C., Gyawali, M., Zaveri, R. A., Shilling, J. E., and Arnott, W. P.: Light absorption by secondary organic aerosol from $\alpha$-pinene: Effects of oxidants, seed aerosol acidity, and relative humidity, J. Geophys. Res.-Atmos., 118, 11741-11749, doi:10.1002/jgrd.50767, 2013.
Updyke, K. M., Nguyen, T. B., and Nizkorodov, S. A.: Formation of brown carbon via reactions of ammonia with secondary organic aerosols from biogenic and anthropogenic precursors, Atmos. Environ., 63, 22-31, doi:10.1016/j.atmosenv.2012.09.012, 2012.

Wagstrom, K. M. and Pandis, S. N.: Determination of the age distribution of primary and secondary aerosol species using a chemical transport model, J. Geophys. Res.-Atmos., 114, D14303, doi:10.1029/2009JD011784, 2009.

Washenfelder, R. A., Attwood, A. R., Brock, C. A., Guo, H., Xu, L., Weber, R. J., Ng, N. L., Allen, H. M., Ayres, B. R., Baumann, K., Cohen, R. C., Draper, D. C., Duffey, K. C., Edgerton, E., Fry, J. L., Hu, W. W., Jimenez, J. L., Palm, B. B., Romer, P., Stone, E. A., Wooldridge, P. J., and Brown, S. S.: Biomass burning dominates brown carbon absorption in the rural southeastern United States, Geophys. Res. Lett., 42, 653-664, doi:10.1002/2014GL062444, 2015.

Zarzana, K. J., De Haan, D. O., Freedman, M. A., Hasenkopf, C. A., and Tolbert, M. A.: Optical Properties of the Products of $\alpha$ Dicarbonyl and Amine Reactions in Simulated Cloud Droplets, Environ. Sci. Technol., 46, 4845-4851, doi:10.1021/es2040152, 2012.

Zhang, X., Lin, Y.-H., Surratt, J. D., Zotter, P., Prévôt, A. S. H., and Weber, R. J.: Light-absorbing soluble organic aerosol in Los Angeles and Atlanta: A contrast in secondary organic aerosol, Geophys. Res. Lett., 38, L21810, doi:10.1029/2011GL049385, 2011.

Zhang, X., Lin, Y.-H., Surratt, J. D., and Weber, R. J.: Sources, Composition and Absorption Ångström Exponent of Lightabsorbing Organic Components in Aerosol Extracts from the Los Angeles Basin, Environ. Sci. Technol., 47, 3685-3693, doi:10.1021/es305047b, 2013.

Zhang, X., Cappa, C. D., Jathar, S. H., McVay, R. C. Ensberg, J. J., Kleeman, M. J., and Seinfeld J. H.: Influence of vapor wall loss in laboratory chambers on yields of secondary organic aerosol, P. Natl. Acad. Sci., 111, 5802-5807, doi:10.1073/pnas.1404727111, 2014.

Zhong, M. and Jang, M.: Light absorption coefficient measurement of SOA using a UV-Visible spectrometer connected with an integrating sphere, Atmos. Environ., 45, 4263-4271, doi:10.1016/j.atmosenv.2011.04.082, 2011.

Zhong, M. and Jang, M.: Dynamic light absorption of biomassburning organic carbon photochemically aged under natural sunlight, Atmos. Chem. Phys., 14, 1517-1525, doi:10.5194/acp-141517-2014, 2014. 